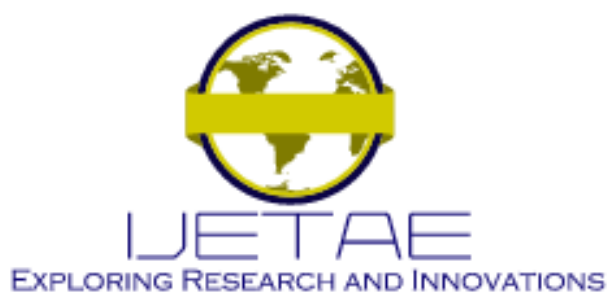

International Journal of Emerging Technology and Advanced Engineering

Website: www.ijetae.com (E-ISSN 2250-2459, Scopus Indexed, ISO 9001:2008 Certified Journal, Volume 12, Issue 02, February 2022)

Manuscript Received: 02 January 2022, Received in Revised form: 01 February 2022, Accepted: 05 February 2022

DOI: $10.46338 /$ ijetae0222_11

\title{
Mobile Application on Stopping the Contagion of Covid-19 to Reduce Congestion in Hospitals
}

\author{
Claudia Romero-Andrade ${ }^{1}$, Enrique Lee Huamaní ${ }^{2}$, Alexi Delgado ${ }^{3}$ \\ ${ }^{1}$ Systems Engineer Program, Universidad de Ciencias y Humanidades, Lima-Perú \\ ${ }^{2}$ Image Processing Research Laboratory, Universidad de Ciencias y Humanidades, Lima Perú \\ ${ }^{3}$ Mining Engineering Section, Pontificia Universidad Católica del Perú, Lima-Perú
}

\begin{abstract}
In 2020 the first case of COVID-19 was reported in Peru, the number of infected people was confirmed to be $1,001,227$ people in the country, there was congestion in hospitals and only COVID-19 cases were attended, canceling patients' appointments. It was proposed the realization of the prototypes of the mobile application to reduce congestion in hospitals where the user registers his symptoms. The scrum methodology was used since it benefits in the realization of work that requires little time. As a result, 20 people from different districts were surveyed about the operation of the mobile application and prototypes were made about the operation of the application that will obtain the user's personal data, the answer to the questions that will be administered by the hospitals, and the results will be sent by e-mail or text message.
\end{abstract}

Keywords-mobile application, congestion in hospitals, COVID-19.

\section{INTRODUCTION}

On March 6, 2020, the President of Peru announced the first case of contagion of coronavirus in the country, the Ministry of Health (Minsa) asked the population to remain calm, on December 18, the number of infected was confirmed. than 1,001,227 people in the country, carrying out molecular tests, rapid tests to citizens, having congestion in hospitals, only COVID-19 cases were attended by canceling patient appointments, currently the number of infected is 2,155 .034 people, total deaths is 198,488 people and hospital discharges are 85,043 people in the country [1].

Similar applications that are considered for this research can be seen in the case of Morocco, which developed a mobile application that consists of following up people who had COVID-19, offering information on appropriate medications for patients, allows identifying symptoms and people who have had contact with COVID-19 positive patients by sending alert messages, this application helps to reduce congestion in hospitals [2].
In the case of Thailand, a mobile application was developed to reduce congestion in hospitals, helping patients to identify their symptoms and following up patients with COVID-19 using a hospital network, the application benefits patients' needs [3]. The COWAR application connects patients with physicians, identifies symptoms and the quantity of contagion, and provides details on COVID-19 prevention [4].

The objective of this research is to reduce congestion in hospitals, have the application help people identify their symptoms, send alert messages to people who have had contact with COVID-19 positive patients, have adequate drug information and follow up for COVID-19 positive patients.

For this research work, the scrum methodology will be used, where the user stories will be according to the user's need, for example, family of patients with COVID-19.

The mobile application will be developed in Java language, and will be used in the Android Studio Platform that will allow us to develop the application with the SQL server database connection.

\section{Methodology}

The Scrum methodology will be used for the research work, the advantage of using this methodology is that partial deliveries are made and it benefits the user of the project, it is useful for projects that can be complex and that are required to have results in the short term [5].

Prototypes of the application will be made through an analysis, in order to reduce congestion in hospitals, so that they can identify their symptoms and be informed about the prevention of COVID-19. 


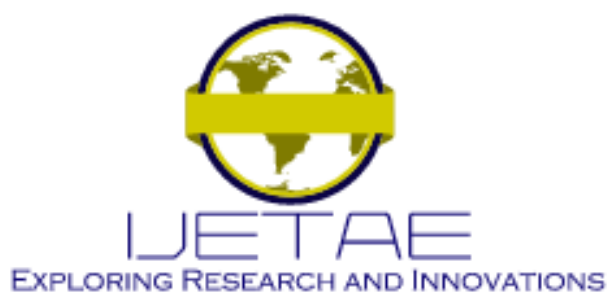

International Journal of Emerging Technology and Advanced Engineering

Website: www.ijetae.com (E-ISSN 2250-2459, Scopus Indexed, ISO 9001:2008 Certified Journal, Volume 12, Issue 02, February 2022)

\section{A. Scrum methodology:}

Scrum is an agile methodology that provides flexibility for the control of requirements for software development, scrum was designed to increase the production capacity of the development process, it is a flexible model that can be applied to any type of organization and can be very useful for small and large projects [6].

\section{a) Order book planning:}

It is analyzed and updated what will be delivered in the sprint and how it will be done, where the responsible for the product is the Product Owner who is responsible for the backlog items are updated and prioritized, so that the development team knows what will be done and how long it will take to do it. [7]. User stories will be obtained by surveying 20 people from different districts on how the mobile application works.

\section{b) Sprint development:}

The sprint is a time interval that has a maximum of one month, during the sprint the increment of a deliverable is developed, where the project team strives to achieve the objective, in each phase of the sprint it must be respected by the team. do not make changes during it, it is recommended that the most important thing that is for the client be completed [8].

c) Development of prototypes:

The prototypes will be used to get an idea of how the application will be realized taking into account the user stories. The prototype will show the user's session design and will have the option to choose between symptoms, prevention and statistical data.

\section{CASE STUdY}

\section{A. Backlog planning:}

Next, the user stories that were obtained through a survey carried out with 20 people from the districts of Comas, San Martin de Porres, Los Olivos, San Juan de Lurigancho San Miguel, Villa María del triunfo, Magdalena de Mar will be shown, Callao and Villa el Salvador that was carried out with Google form, on the operation of the mobile application.
Table 1

User Stories

\begin{tabular}{|l|l|}
\hline Nro. & User Stories \\
\hline 1 & $\begin{array}{l}\text { As a patient I want you to send me a } \\
\text { message to the email of the result. }\end{array}$ \\
\hline 2 & $\begin{array}{l}\text { As a patient, I want to see how to prevent } \\
\text { contagion against COVID-19. }\end{array}$ \\
\hline 3 & $\begin{array}{l}\text { As a patient I want you to allow me to } \\
\text { record the symptoms. }\end{array}$ \\
\hline 4 & $\begin{array}{l}\text { As a patient I want to see the number of } \\
\text { infected in Peru. }\end{array}$ \\
\hline 5 & $\begin{array}{l}\text { Como paciente quiero poder registrar mis } \\
\text { datos personales. }\end{array}$ \\
\hline 6 & $\begin{array}{l}\text { As a patient I want there to be a choice of } \\
\text { treatment or medications to take. }\end{array}$ \\
\hline
\end{tabular}

\section{B. Sprint Development:}

The following table will show the sprints that will be carried out in the development of the application.

Table 2

Sprint Development

\begin{tabular}{|l|l|}
\hline $\begin{array}{l}\text { Sprint } \\
1\end{array}$ & 1. Record the patient's symptoms. \\
\hline $\begin{array}{l}\text { Sprint } \\
2\end{array}$ & $\begin{array}{l}\text { 2. Record the patient's personal data. } \\
\text { 3. Option on how to prevent contagion. }\end{array}$ \\
\hline Sprint & $\begin{array}{l}\text { 4. Sending a message to the email about } \\
\text { the result. }\end{array}$ \\
& $\begin{array}{l}\text { 5. Quantity of contagions in Peru. } \\
\text { 6. Treatment option or medications to be } \\
\text { taken. }\end{array}$ \\
\hline
\end{tabular}

C. Technological tools:

The technological tools that will be used in the mobile application are:

1) Android studio: It is an IDE application that is used to create applications on android, which is equipped with an emulator, it is also a system for devices such as android, android tv, android auto [9].

2) SQL server: It is a database management system, its query language is transact-Sql, which is based on a relational model [10].

3) Java: It is a programming language that can be used to design applications that run on the computer, servers, it can also be used to build an application module [11]. 


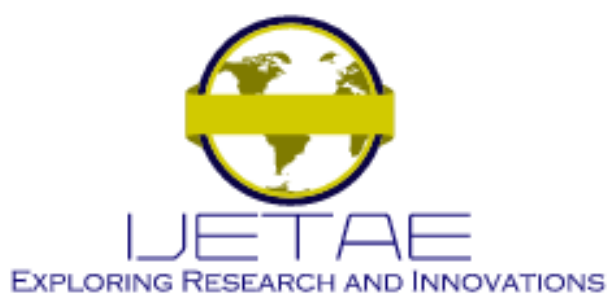

International Journal of Emerging Technology and Advanced Engineering Website: www.ijetae.com (E-ISSN 2250-2459, Scopus Indexed, ISO 9001:2008 Certified Journal, Volume 12, Issue 02, February 2022)

Next, Figure 1 shows the process of operation of the mobile application, the application begins when the user starts the process of user registration and password, when you finish registering and click the next button, it will show a screen asking if you have had contact with a patient with COVID-19, to respond a screen for the user to register their data will be displayed their data for example, full names, age, address, phone or cell phone, email, after filling out their personal data, it will show a screen with a variety of questions about the symptoms that the user has, when saving the data will be stored in the SQL server database data, the information will be received by the hospital, the result of the user will be sent to your email address.

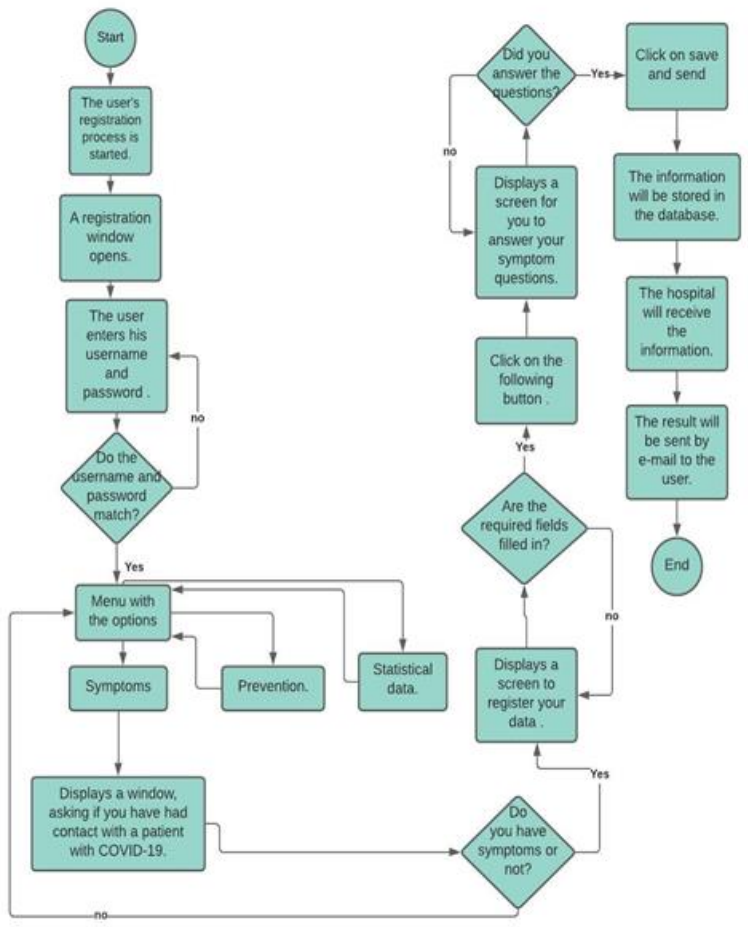

Figure 1: Flowchart of the mobile application.

Figure 2 shows the proposed architecture for the mobile application, it will be done in Android studio which is a development environment (IDE) with the 5.0 version, with the Java programming language and to access the SQL server, the JDBC driver for the SQL server.
For the connection it is necessary to enter the address of the database server, access, instance, user and password. Then the information obtained from the user will be stored in SQL server, the information will be administered in an Excel file to the hospitals, and once the results are obtained, they will be sent by the hospital server to the user's e-mail address.

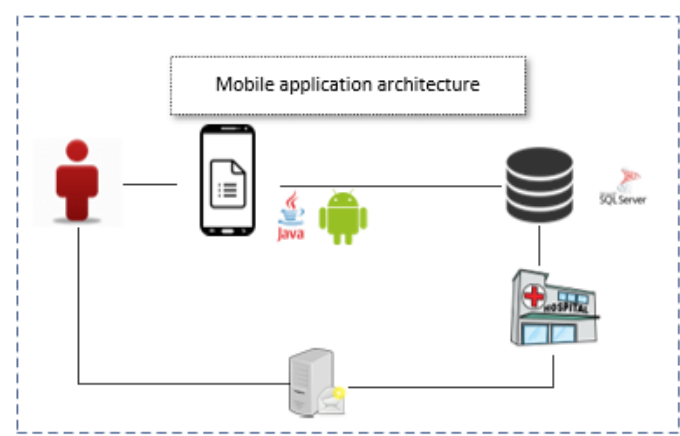

Figure 2: Proposed architecture of the mobile application.

\section{RESULTS}

\section{A. Respondents:}

In the respondent's section, 20 people from the districts of Comas, San Martin de Porres, Los Olivos, San Juan de Lurigancho San Miguel, Villa María del triunfo, Magdalena de Mar, Callao and Villa el Salvador were surveyed about the functioning of the mobile application.

Figure 3 shows the quantity of people surveyed, $80 \%$ of the people surveyed were men and $20 \%$ were women. Figure 4 shows the response to the question: Do you believe that the mobile application can reduce congestion in hospitals? $15 \%$ of the respondents answered yes, $80 \%$ answered no and 5\% answered that they do not know how it works.

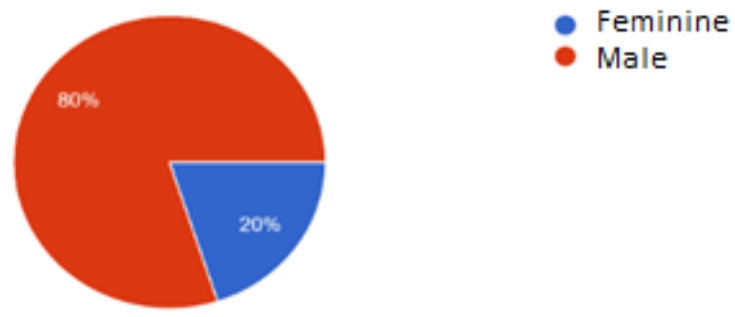

Figure 3: Respondents' graph. 


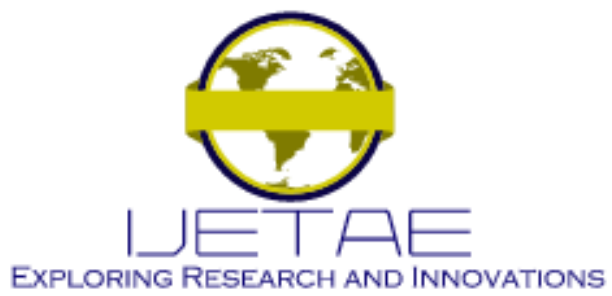

International Journal of Emerging Technology and Advanced Engineering

Website: www.ijetae.com (E-ISSN 2250-2459, Scopus Indexed, ISO 9001:2008 Certified Journal, Volume 12, Issue 02, February 2022)

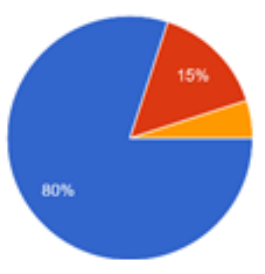

- YES

- NO

I do not know how it works

Figure 4: Graph of whether the application can reduce co-management.

Figure 5 shows the response to the question: Do you want the Mobile Application to be able to register the COVID-19 Symptoms? $80 \%$ of respondents said yes and $20 \%$ said no.

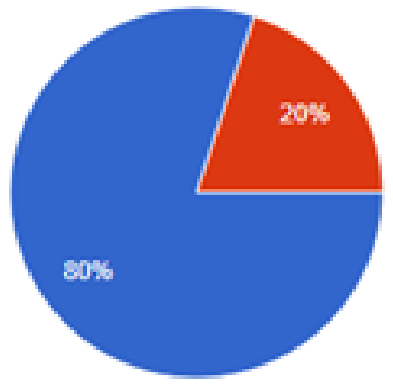

YES

NO

Figure 5: Graphic of whether you want the application to be able to record the symptoms of COVID-19.

\section{B. Project prototype:}

Next, we will present the prototypes related to the user stories shown in Table 1. We will show the message that the user receives in the e-mail, where he/she will give a brief description of the result, attaching a file in pdf format. Figure 7 shows how to prevent COVID-19, as shown in the image using double masks, washing hands, having 1 meter of distance.

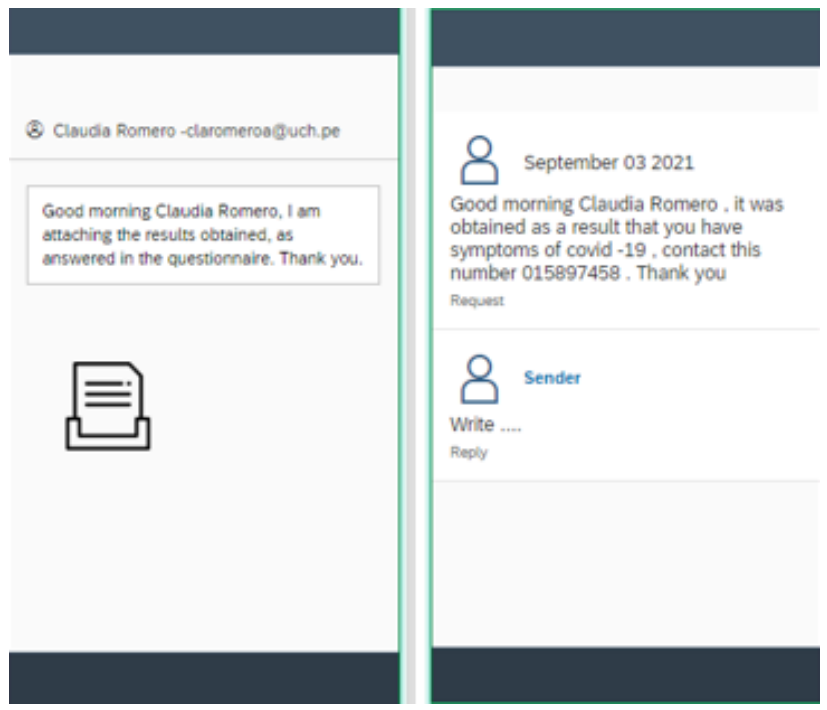

Figure 6: E-mail message and text message.

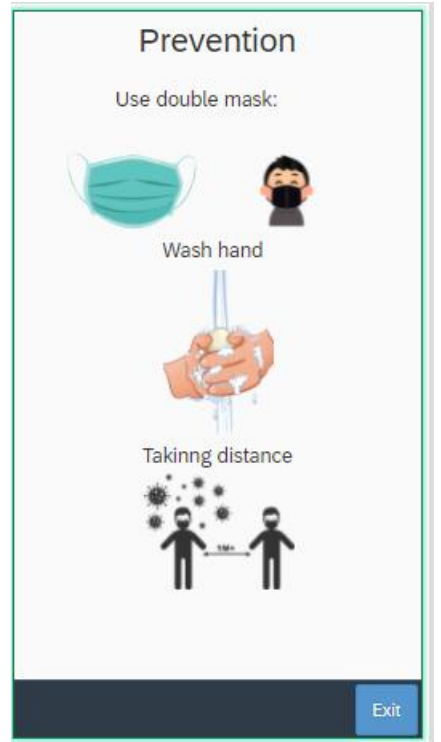

Figure 7: Image of how to prevent contagion 


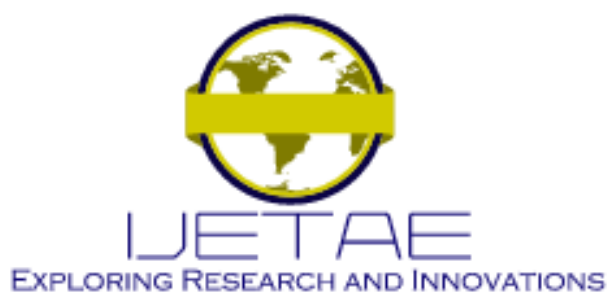

International Journal of Emerging Technology and Advanced Engineering Website: www.ijetae.com (E-ISSN 2250-2459, Scopus Indexed, ISO 9001:2008 Certified Journal, Volume 12, Issue 02, February 2022)

Figure 8 shows the registration of symptoms, which is raised by a variety of questions that have the option to select, check yes or no, among the questions that were asked are: If you have had contact with patients with COVID-19, Do you have cough, do you have fever, and if you suffer from any disease? Figure 9 shows the quantity of contagions in Peru by means of statistical graphs such as: histogram and pie chart of the quantity of contagions of COVID-19 in Peru.

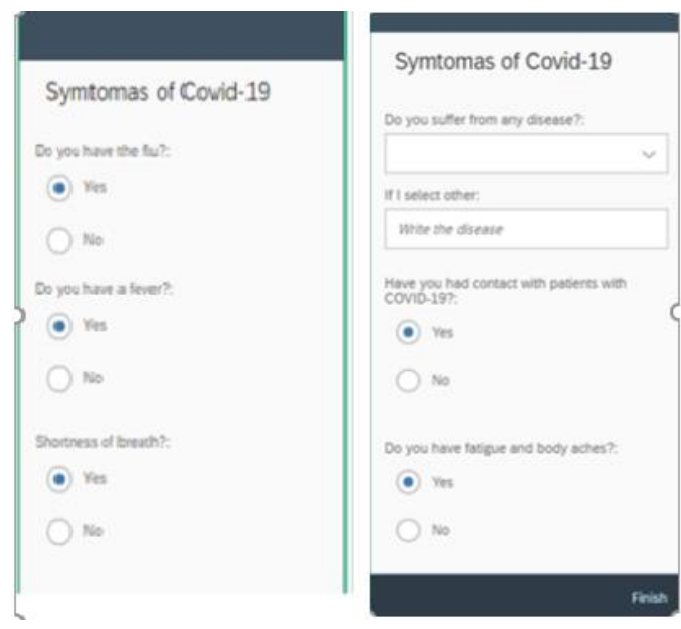

Figure 8: Recording of patient symptoms.

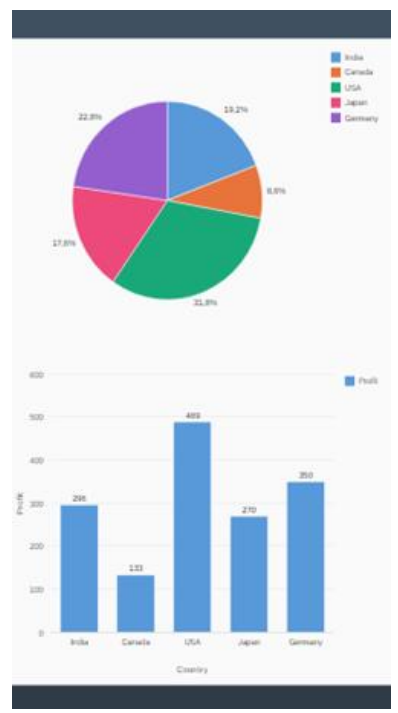

Figure 9: Quantity of contagion in Perú.
Figure 10 (a) shows the user record, such as: full names, age, address, district, province and email address. Figure 10 (b) shows options such as: symptoms, prevention and statistical data.

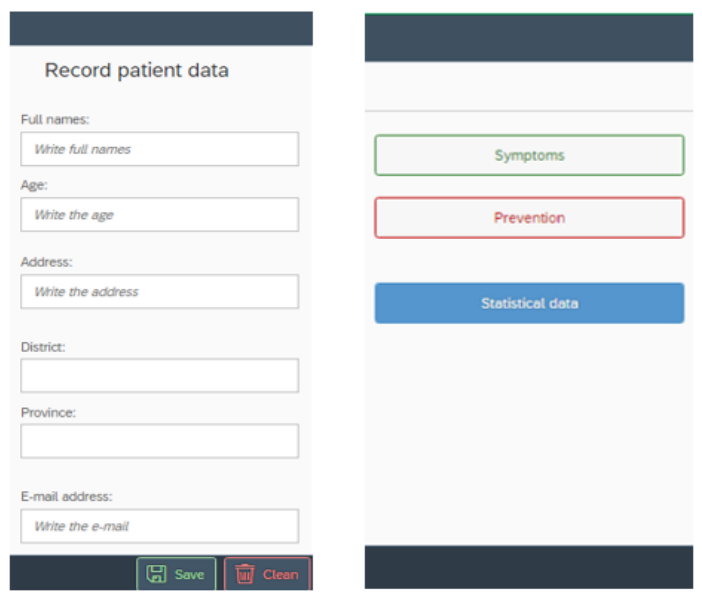

(a) Patient registration. (b) Symptom options, prevention or statistical data.

Figure 10: Record of user data and options for symptoms, prevention or statistical data

\section{DISCUSSION}

In the work [2] was made a mobile application that consists of following up people who had COVID-19 offering information on appropriate medications for patients, allowing to identify the symptoms and people who have had contact with patients who tested positive by sending alert messages, which is similar to the proposed project that is to identify user symptoms, however does not show a section of respondents on the operation of the mobile application, instead the project shows a survey that was conducted to 20 people on the operation of the mobile application with their respective statistical graphs.

The research work will identify the symptoms of the users, it will be done by means of a form and the answer obtained, which will facilitate obtaining the user's information and if it is positive, it will be possible to follow up.

The research work on a mobile application focused on the identification of users' symptoms and did not consider implementing alert messages to people who had contact with COVID-positive patients-19, and is considered for implementation in another research work. 


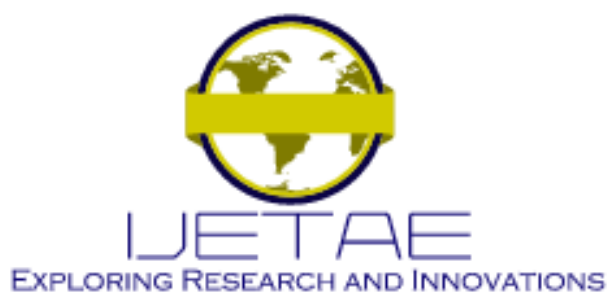

International Journal of Emerging Technology and Advanced Engineering Website: www.ijetae.com (E-ISSN 2250-2459, Scopus Indexed, ISO 9001:2008 Certified Journal, Volume 12, Issue 02, February 2022)

\section{CONCLUSIONS}

In the research work, a prototype of the mobile application was made for the identification of symptoms, you will have the options of visualizing the number of infected in Peru through statistical graphics and how to prevent contagion. In this way, it is necessary to reduce the co-management of hospitals in Peru. In the results obtained, a survey was conducted with 20 people from different districts on the operation of the mobile application, with the help of the scrum methodology, prioritize user stories and divide them into Sprint to design the prototypes. It is recommended as future work to implement a map showing the number of infected in Peru and the user's vaccination place.

\section{REFERENCES}

[1] «Grupo La República, » [En línea]. Available: https://data.larepublica.pe/envivo-casos-confirmados-muertescoronavirus-peru/.

[2] M. Berquedich, A. Berquedich, O. Kamach, M. Masmoudi, A. Chebbak y L. Deshayes, «Developing a Mobile COVID-19 Prototype Management Application Integrated with an Electronic Health Record for Effective Management in Hospitals, » vol. 48, $\mathrm{n}^{\circ}$ 4, p. 10, Diciembre, doi: 10.1109/EMR.2020.3032943.

[3] K. I. DebraOlsonSuwatChariyalertsak, «Application technology to fight the COVID-19 pandemic: Lessons learned in Thailand, » vol. 534, p. 7, Enero, doi: 10.1016/j.bbrc.2020.10.097.
[4] T. Saxena, P. Anuragi, G. Shinde, N. Yadav and M. Digalwar, "COWAR: An Android Based Mobile Application to Help Citizens and COVID-19 Warriors," 2020 IEEE 4th Conference on Information \& Communication Technology (CICT), 2020, pp. 1-6, doi: 10.1109/CICT51604.2020.9312073.

[5] conexionesan, 1 Junio 2017. [En línea]. Available: https://www.esan.edu.pe/apuntes-empresariales/2017/06/que-es-elscrum-y-por-que-es-importante-desarrollarlo-en-un-proyecto/.

[6] F. Hayat, A. U. Rehman, K. S. Arif, K. Wahab and M. Abbas, "The Influence of Agile Methodology (Scrum) on Software Project Management," 2019 20th IEEE/ACIS International Conference on Software Engineering, Artificial Intelligence, Networking and Parallel/Distributed Computing (SNPD), 2019, pp. 145-149, doi: 10.1109/SNPD.2019.8935813.

[7] J. Ramos Romero y J. Lujan Barta, «Prototype of A Monitoring and Prevention System for People Vulnerable to Cardiac Arrest and Covid-19 Using IoT and SAP Cloud Platform, » IJETT, vol. 69, p. 6, 2021, doi:10.14445/22315381/IJETT-V69I6P214.

[8] «Be Agile My Friend, » 2021. [En línea]. Available: https://beagilemyfriend.com/que-es-un-sprint/.

[9] K. Nugroho, Sumardi, S. Murdowo and Muljono, "Mobile Cloud Learning System Using Laravel Framework and Android Studio Web View," 2019 International Seminar on Application for Technology of Information and Communication (iSemantic), 2019, pp. 141-144, doi: 10.1109/ISEMANTIC.2019.8884275.

[10] J.Santamaría,J. Hernández," Microsoft SQL Server" https://iessanvicente.com/colaboraciones/sqlserver.pdf

[11] R. V. Golhar, P. A. Vyawahare, P. H. Borghare and A. Manusmare, "Design and implementation of android base mobile app for an institute," 2016 International Conference on Electrical, Electronics, and Optimization Techniques (ICEEOT), 2016, pp. 3660-3663, doi: 10.1109/ICEEOT.2016.7755391. 